\title{
Physical and chemical variability of Camu-camu fruits in cultivated and uncultivated areas of the Colombian Amazon
}

\author{
Juan Carlos Aguirre-Neira ${ }^{1}$, Maurício Sedrez dos Reis ${ }^{2}$, \\ Maritza Adelina Rojas Cardozo ${ }^{3}$, Lauren Raz ${ }^{4}$, Charles Roland Clement ${ }^{5}$
}

\begin{abstract}
Camu-camu (Myrciaria dubia, Myrtaceae) has the highest reported vitamin C concentrations of any native Amazonian fruit tree species, with increasing demand in domestic and international markets. With the goal of aiding management and conservation programs, we studied the diversity of camu-camu in cultivated and uncultivated areas, based on physicochemical characterization of the fruits. We evaluated 2,250 fruits from 87 plants from six localities of the Tarapacá district (Amazonas, Colombia) and from the Amazonian fruit germplasm bank of Agrosavia (Meta, Colombia). We found high physicochemical variability within and among localities, and superior fruits in the localities where non-cultivated plants were sampled, especially Pechiboy. Using correlations and principal component analyses, we identified the variables Brix value, ascorbic acid content, fruit weight and pulp yield as the most useful for intraspecific selection of plants. The most promising plants presented Brix values of $8.2 \pm 0.88$ (maximum 10.9), fruit mass of 14.4 $\pm 1.2 \mathrm{~g}$ (max. $18.4 \mathrm{~g}$ ) and pulp yields of $0.82 \pm 0.02$ (max. 0.87 ). These plants can be considered as possible sources for future breeding work. We conclude that there are plants in Tarapacá with relevant characteristics for commercialization and improvement of the species.
\end{abstract}

Index Terms: Tarapacá, Myrciaria dubia, selection, improvement

\section{Variabilidade físico-química de frutos de Camu-camu em áreas cultivadas e não cultivadas da \\ Amazônia Colombiana}

Corresponding author: jcaguirren@unal.edu.co

Received: August 26, 2019 Accepted: January 17, 2020

Copyright: All the contents of this journal, except where otherwise noted, is licensed under a Creative Commons Attribution License.

(cc) $\mathbf{E Y}$
Resumo- O camu-camu (Myrciaria dubia, Myrtaceae) possui as mais altas concentrações de vitamina $\mathrm{C}$ relatadas em frutíferas nativas da Amazônia, com uma demanda crescente nos mercados nacional e internacional. Visando aos processos de manejo e à conservação da espécie, estudou-se a diversidade de camu-camu em áreas cultivadas e não cultivadas, a partir da caracterização físico-química de frutos. Foram avaliados 2.250 frutos de 87 plantas procedentes de 6 localidades do distrito de Tarapacá (Amazonas - Colômbia) e do banco de germoplasma de frutíferas amazônicas de Agrosavia (Meta - Colômbia). Encontrou-se alta variabilidade físico-química entre e dentro das localidades, com frutos superiores nas localidades onde foram amostradas plantas não cultivadas, destacando-se Pechiboy. Os resultados por correlações e componentes principais permitiram identificar as variáveis graus Brix, vitamina $\mathrm{C}$, massa de fruto e rendimento de polpa como as mais úteis para a seleção intraespecífica de plantas. Foram identificadas plantas com valores promissores de graus Brix $(8,2 \pm 0,88$; máximo 10,94$)$, massa de fruto $(14,4 \pm 1,2 \mathrm{~g}$; máx. $18,4 \mathrm{~g})$ e rendimento de polpa $(0,82 \pm 0,02$; máx. 0,87$)$. Essas plantas podem ser consideradas como possíveis matrizes para futuros processos de melhoramento. Concluiu-se que existem em Tarapacá plantas com características relevantes para processos de comercialização e de melhoramento da espécie.

Termos para indexação: Tarapacá, Myrciaria dubia, seleção, melhoramento.

${ }^{1} \mathrm{PhD}$ student in Plant Genetic Resources, Universidade Federal de Santa Catarina, Florianópolis-SC, Brazil. Scholarship holder of the Students-Graduate Agreement Program - PEC-PG, from CAPES / CNPq- Brazil. Part of the doctoral thesis of the first author. E-mail: jcaguirren@unal.edu.co ${ }^{\text {(ORCID 000- }}$ 0002-7868-3724).

${ }^{2} \mathrm{PhD}$ Professor in Plant Genetic Resources, Universidade Federal de Santa Catarina, Florianópolis-SC, Brazil. E-mail: msedrez@gmail.com ${ }^{\text {(ORCID }}$ 0000-0003-1331-3367)

${ }^{3} \mathrm{PhD}$ Professor in Pharmacy Department, Universidad Nacional de Colombia, Bogotá, Colombia. E-mail: marojasc@unal.edu.co(ORCID 0000-00021066-4332)

${ }^{4} \mathrm{PhD}$ Professor, Instituto de Ciencias Naturales, Universidad Nacional de Colombia, Bogotá, Colombia. E-mail: 1raz@unal.edu.co(ORCID 0000-00023152-4726)

${ }^{5}$ PhD Professor, Instituto Nacional de Pesquisas da Amazônia (INPA), Manaus-AM, Brazil E-mail: cclement@inpa.gov.br (ORCID 0000-0002-84211029) 


\section{Introduction}

In the Colombian Amazon, as well as in the Brazilian and Peruvian Amazon, camu-camu [Myrciaria dubia (Kunth) McVaugh] is a promising non-timber forest product because it is a natural source of vitamin $\mathrm{C}$ and other compounds relevant to human health (MORAIS; PINHEIRO, 2018; AVILA-SOSA et al., 2019). Thanks to these properties, it is a product with increasing demand in national and international markets (PROMPERU, 2018). Currently, Peru is the main producer and exporter of camu-camu in the world, with exports of 177 tons of pulp, equivalent to sales of US $\$ 2.6$ million (PROMPERU, 2018). However, $85 \%$ of this camu-camu comes from uncultivated areas, i.e., it is collected from natural stands in the floodplains of the upper Amazon River and its tributaries (IZQUIERDO GÓMEZ; TONG GATTY, 2018). Paradoxically, little is known about the state of the morphological variability of camu-camu that grows in uncultivated areas (MARTIN et al., 2014; ŠMÍD et al., 2017). Hence, information about camu-camu in these uncultivated localities, as well as evaluation of the quality of materials in nearby cultivated areas, can contribute to the process of domestication and improvement of the species, as well as to the conservation and management of uncultivated populations and the ecosystems of which they are part (ŠMÍD et al., 2017).

Despite years of research, camu-camu is still in the process of domestication (PINEDO-PANDURO et al., 2004). Therefore, uncultivated plants, as well as cultivated plants, still show great phenotypic variability in their various morphological, physiological and agronomic characteristics (PINEDO-PANDURO et al., 2004; ŠMÍD et al., 2017). Since the cultivated populations of camucamu have not yet been highly selected for morphological characteristics of the fruits, there is still potential to select plants with larger fruits from uncultivated populations (ŠMíD et al., 2017).

In order to identify and select elite plants (BRASIL, 2003) for domestication and improvement processes, numerous studies agree that the variables with greater discriminatory capacity for intraspecific selection of camucamu are fruit mass, pulp yield, Brix value and ascorbic acid content (NASCIMENTO et al., 2014; CHAGAS et al., 2015; PINEDO-PANDURO, 2017). Some authors used principal component analysis (PCA) to identify sets of discriminatory variables for intraspecific selection of camu-camu with similar results (IMÁN-CORREA et al., 2011; CHAGAS et al., 2015; FREITAS et al., 2016).

The Tarapacá district is the only region in Colombia known to have monospecific stands larger than 5,000 $\mathrm{m}^{2}$ of uncultivated camu-camu. In this region, the first commercial initiative to supply fruits to national markets is being developed (HERNÁNDEZ et al., 2010a). To contribute information to support this effort to use, manage and conserve camu-camu, this study (the first in Colombia) analyzed fruit physicochemical diversity in cultivated and uncultivated areas.

\section{Material and methods}

Camu-camu fruits were collected in the district of Tarapacá, Colombia (coordinates of the urban area: $2^{\circ} 53$ '31.61 "S, 6944'30.48" O, altitude $54 \mathrm{~m}$ ). The samples were collected from cultivated $(\mathrm{n}=12)$ and uncultivated $(n=75)$ plants. The cultivated plants were found in home gardens or other places close to the family residence, in areas without periodic flooding. On the other hand, plants from uncultivated areas occur in riparian zones of the Cotuhé and Içá-Putumayo rivers (with flood periods of more than two months) and are dispersed along streams or aggregated in abandoned meander lakes, forming monospecific stands (Figure 1). The soils in both areas are acidic and have textures between sandy and clayey. However, cultivated areas have deep soils with low fertility, whereas soils in uncultivated areas are shallow with moderate fertility (CÁRDENAS et al., 2004). These factors also determine different types of vegetation cover. While tall dense forests on terra firme predominate in cultivated areas, heterogeneous tall dense forests predominate in uncultivated areas (RINCÓN et al., 2009).

In areas with uncultivated plants, trees were sampled every 100 meters across the entire area, choosing individuals that had 15 to 30 fruits in maturation stages 4 and 5 (HERNÁNDEZ et al., 2010b). The collections were made between 28 February and 02 April 2018, and all the plants sampled were georeferenced and identified with metal tags. Fifteen to 30 fruits per plant were measured individually, with a total of 2,250 fruits, collected from 87 camu-camu plants, from four uncultivated locations (Isla $-\mathrm{n}=24$; Pechiboy $-\mathrm{n}=29$; Santa Clara $-\mathrm{n}=17$; Rio $-\mathrm{n}=5$ ) and tree cultivated locations (Tarapacá $-\mathrm{n}=$ 6; Ventura - $n=3$; Agrosavia - $n=3$ ) (Figure 1).

The physicochemical characteristics evaluated were: Brix value (in triplicate, using a digital refractometer with $0.1 \%$ precision); fruit mass (FM) and mass of seeds per fruit (MSF) (using a semi-analytical balance with precision of $0.01 \mathrm{~g}$ ); number of seeds per fruit (NSF); fruit length (polar diameter) (FL) and mean fruit diameter (MFD) (equatorial diameter) (using a digital caliper with precision of $0.01 \mathrm{~mm}$ ). The pulp mass $(\mathrm{PM})$ was calculated as FM - SMF, and the pulp yield (PUY) as PM / FM. The characteristics PM and PUY included the fruit mesocarp and exocarp, since functional compounds, such as vitamin $\mathrm{C}$, are mainly concentrated in the exocarp of the fruit (NEVES et al., 2015). Pulp moisture content was estimated for each plant from a sample of pulp (mesocarp + exocarp) from all its fruits, weighed before and after drying for 72 hours in an oven with hot air circulation at $60{ }^{\circ} \mathrm{C}$. 


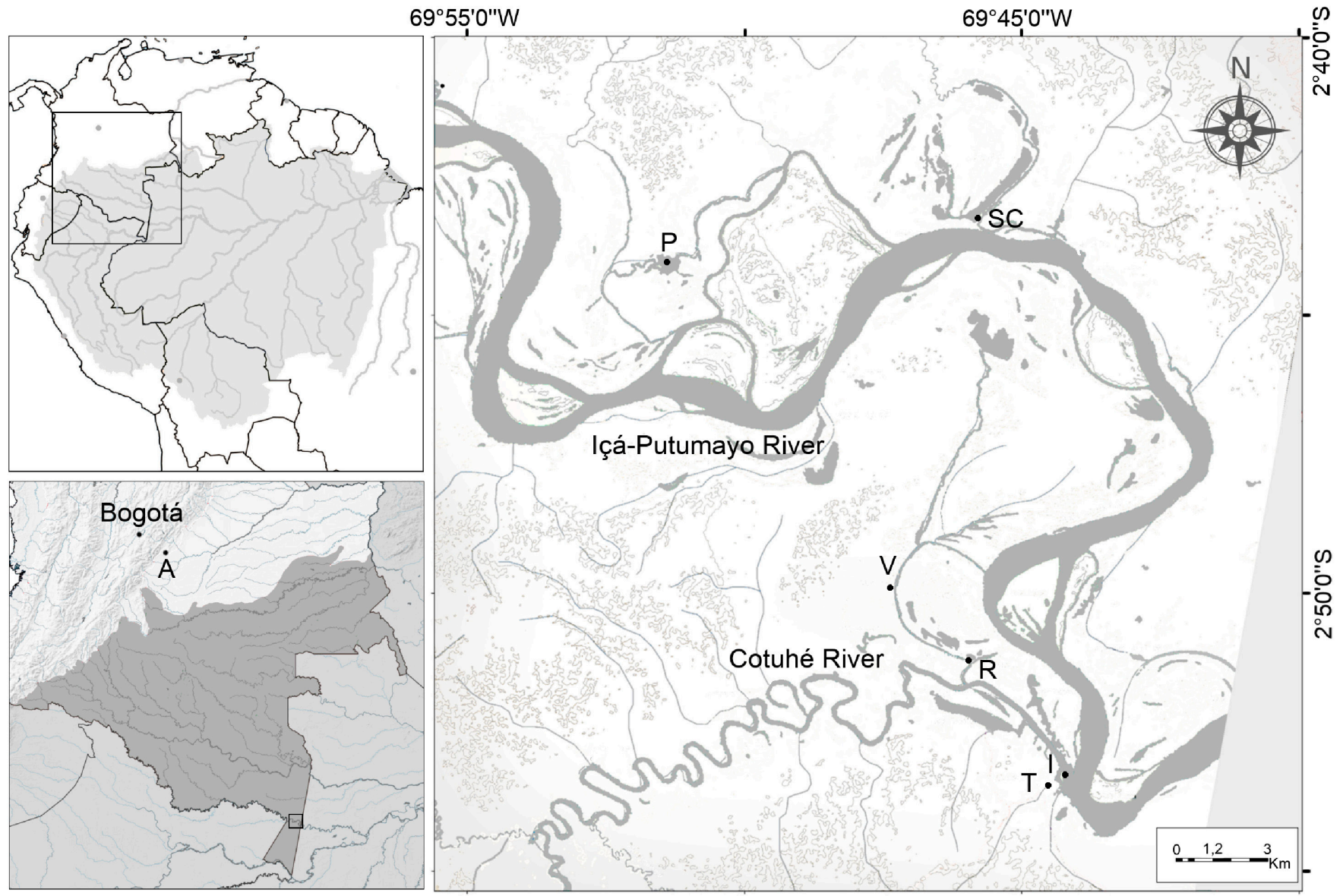

Figure 1. Study areas in Colombia. Letters represent the collection points: Agrosavia (A), Pechiboy (P), Santa Clara (SC); Ventura (V); Rio (R); Isla (I); Tarapacá (T). Source: Developed by the first author.

To obtain the ascorbic acid content per plant (commonly termed vitamin $\mathrm{C}$ content), samples were dried for 72 hours in an oven with hot air circulation at $60{ }^{\circ} \mathrm{C}$. Each dry sample was ground, stored in an airtight plastic bag and protected from light at room temperature. The Tillmans method (1927) was used, replacing metaphosphoric acid with oxalic acid (BENASSI; ANTUNES, 1988), and following the physicochemical method for food analysis no. 365 / IV of the Instituto Adolfo Lutz (2008). The samples were rehydrated in a 1:10 ratio ( $\mathrm{g}$ of dry pulp : $\mathrm{ml}$ of distilled water) and then solubilized in $2 \%$ oxalic acid in a 1:1 ratio, with subsequent stirring for 15 minutes, vacuum filtration and titration (SOUZA, 2012; JULIANO et al., 2014). The results were expressed in mg of ascorbic acid per $100 \mathrm{~g}$ of pulp (mesocarp + exocarp). This determination of vitamin $\mathrm{C}$ content was made at the Laboratory of Developmental Physiology and Plant Genetics, Center for Agricultural Sciences, Universidade Federal de Santa Catarina, Florianópolis. The remaining characteristics were measured in the Laboratory of the Pharmacognosy and Phytochemistry Group (GIFFUN) at the Universidad Nacional de Colombia, Bogotá.

Descriptive statistics were estimated for all variables (mean, mode (for NSF), standard deviation, amplitude, coefficient of variation and confidence intervals (95\%) from 10,000 bootstrap replicates (CHERNICK; LABUDDE, 2011)) in order to compare cultivateduncultivated groups and localities. No confidence intervals were calculated for locations with less than 15 plants. Correlations between the evaluated characteristics were also estimated and principal component analysis (PCA) was carried out. The dplyr (descriptive), stats (correlation) and psych (PCA) packages were used in R v. 3.3.4 (R DEVELOPMENT CORE TEAM, 2018). In the locations where the uncultivated plants were collected, plants with ascorbic acid content, Brix value, fruit mass and pulp yield values above the third quartile were identified for future use.

\section{Results and discussion}

Previous studies report Brix values ranging from $5 \%$ to $6.3 \%$ in cultivated plants (ALVES et al., 2002; IMÁN-CORREA et al., 2011), all lower than the values found in this study (Table 1), both for cultivated and uncultivated groups and locations. Only Zanatta et al. (2005) report a value greater than $8.5 \%$. In the case of uncultivated plants, Chagas et al. (2015) and Grigio et al. (2016) report values similar to those obtained in this study: between $6.3 \%$ and $7.4 \%$, respectively. 
Table 1. Mean physicochemical parameters of camu-camu (Myrciaria dubia) fruits in the Tarapacá region, Amazonas, Colombia, and identification of differences between cultivated and uncultivated groups and locations by confidence intervals *.

\begin{tabular}{|c|c|c|c|c|c|c|c|c|c|c|c|c|}
\hline \multirow[b]{2}{*}{ Group } & \multirow[b]{2}{*}{ Locality } & \multirow[b]{2}{*}{$\begin{array}{l}\text { Hydrographic } \\
\text { Sub-area }\end{array}$} & \multicolumn{10}{|c|}{ Parameters } \\
\hline & & & $\mathrm{BX}$ & AA & FM & PM & PUY & MFD & FL & MSF & NSF & $\mathrm{MO}$ \\
\hline \multirow{5}{*}{$\begin{array}{l}\text { Uncultivated } \\
\text { plants }\end{array}$} & Isla & Putumayo Bajo River & 6,8 & 205,4 & 11,2 & $8,5 \mathrm{~B}$ & $0,76 \mathrm{~B}$ & 27,2 & 25,4 & 2,7 & 2 & 89,9 \\
\hline & Pechiboy & Putumayo Bajo River & 7,0 & 214,5 & 12,2 & $9,8 \mathrm{~A}$ & $0,80 \mathrm{~A}$ & 28,0 & 25,7 & 2,5 & 3 & 88,2 \\
\hline & Santa Clara & Putumayo Bajo River & 6,3 & 216,5 & 12,7 & $10,0 \mathrm{AB}$ & $0,79 \mathrm{AB}$ & 28,4 & 26,0 & 2,7 & 3 & 87,9 \\
\hline & Rio & Cotuhé River & 5,9 & 201,4 & 11,1 & 8,7 & 0,79 & 26,9 & 25,4 & 2,4 & 2 & 88,5 \\
\hline & Total & & 6,7 & $208,2 \mathrm{a}$ & $11,9 \mathrm{a}$ & $9,3 \mathrm{a}$ & 0,78 & $27,7 \mathrm{a}$ & $25,6 \mathrm{a}$ & 2,6 & 3 & 88,6 \\
\hline \multirow{4}{*}{$\begin{array}{l}\text { Cultivated } \\
\text { plants }\end{array}$} & Tarapacá & Cotuhé River & 6,8 & 167,8 & 10,7 & 8,2 & 0,77 & 26,7 & 24,9 & 2,5 & 3 & 88,5 \\
\hline & Ventura & Cotuhé River & 8,1 & 190,4 & 9,4 & 7,2 & 0,78 & 25,6 & 23,7 & 2,1 & 2 & 87,2 \\
\hline & Agrosavia & -- & 9,5 & ne & 9,4 & 6,9 & 0,74 & 25,5 & 24,0 & 2,5 & 2 & 88,1 \\
\hline & Total & & $1,2^{* n}$ & & & & 0,76 & & & 2,4 & 2 & 58,0 \\
\hline
\end{tabular}

BX: degrees Brix (\%); AA: Ascorbic Acid content (mg / $100 \mathrm{~g}$ of mesocarp + exocarp); FM: fruit mass (g); PM: pulp mass per fruit (g); PUY: pulp yield; MFD: mean fruit diameter (mm); FL: fruit length (mm); MSF: mass of seeds per fruit (g); NSF: number of seeds per fruit (un); MO: Moisture (\%); ne: not evaluated. Means without letters did not show statistical differences between them. Means followed by different letters in the columns differ from each other by confidence intervals constructed from 10,000 bootstrap replicates in each group ( $p<0.05$ ). Lower case letters between groups and upper case letters between uncultivated locations. * For locations with less than 15 plants, no confidence intervals were calculated. ** Due to methodological differences in the measurement of degrees Brix, plants from the Agrosavia germplasm bank were excluded from the estimation of the cultivated average.

The ascorbic acid values found in this study were lower than those reported in the literature, between 1,708 and 5,084 $\mathrm{mg} / 100 \mathrm{ml}$ of fresh pulp (ALVES et al., 2002; CARVALHO; MÜLLER, 2005). The low values found here are mainly due to the process of drying the pulp before transport for analysis. Silva et al. (2005) found that the ascorbic acid content of the pulp decreased by $34 \%$ when dried with hot air at $60{ }^{\circ} \mathrm{C}$ for 240 minutes, while Fujita et al. (2013) found losses of $18 \%$ due to lyophilization at $180^{\circ} \mathrm{C}$ for 120 hours.

The fruit mass of uncultivated plants found in this study (Table 1) exceeded previous reports, which ranged from 5.2 to $13.8 \mathrm{~g}$ (RIBEIRO et al., 2006; OLIVEIRA et al., 2018). On the other hand, the values obtained for pulp yield did not exceed $80 \%$, while the literature reports values between $76.5 \%$ and $92.7 \%$ (RIBEIRO et al., 2006; OLIVEIRA et al., 2018). Pulp yield was affected by seed mass, which had values higher than those in the literature, varying from 0.97 to $2.21 \mathrm{~g}$ of seeds per fruit (CHAGAS et al., 2015; OLIVEIRA et al., 2018).

Uncultivated plants had fruits that were significantly different from cultivated plants in ascorbic acid content, fruit length, fruit diameter, fruit mass and pulp mass (Table 1). These differences between groups can be attributed partially to the effects of environmental factors, such as groundwater and soil fertility. In the case of the ground water, previous research showed that the higher the flood level, the greater the ascorbic acid content of the fruit (PINEDO-PANDURO et al., 2010; PINEDO-PANDURO, 2012). In addition, Abanto-Rodriguez et al. (2016) found that the concentration of ascorbic acid in camu-camu plants is enhanced when the soils have better chemical attributes and good conditions of natural fertility. These observations agree with those reported here, given that the soils of cultivated areas are well drained, without regular flooding and with low fertility, while the soils of uncultivated areas are poorly drained, with regular floods and moderate fertility (CÁRDENAS et al., 2004). These better conditions in uncultivated areas are explained by their location in the Içá-Putumayo basin, a white water river that transports large amounts of sediments eroded from the Andes and deposits them in the floodplains (PNUMA; OTCA, 2008).

With regard to the differences among localities of uncultivated camu-camu, Pechiboy and Santa Clara have larger fruits than those that have been reported to date, in terms of fruit and pulp mass and fruit dimensions. As for the differences between localities, fruit from Pechiboy were superior in most of the characteristics and statistically superior to fruits from Isla in pulp mass and pulp yield (Table 1). On the other hand, although fruits from the localities of Pechiboy and Santa Clara did not differ, it is worth noting that the fruits from Santa Clara tend to have greater mass and size, but the greater mass of seeds directly affects pulp yield.

The camu-camu fruits evaluated had high coefficients of variation $(\mathrm{CV})$ in their physicochemical characteristics, both between groups (cultivated and noncultivated) and within localities. The CVs were greater than $20 \%$ for the variables Brix value, ascorbic acid content, fruit mass, pulp mass, seed mass and number of seeds per fruit. The remaining characteristics had CVs below $10 \%$. Other authors, studying both cultivated and uncultivated camu-camu plants, found similar results (NASCIMENTO et al., 2013; CHAGAS et al., 2015). 
There were high correlations (Table 2) between fruit mass, pulp mass, fruit length and fruit diameter, moderate correlations of these variables with ascorbic acid content, and low correlations with pulp yield. Brix value had a negative correlation with other variables, while pulp yield had a negative correlation with number of seeds per fruit. These correlations are similar to those reported so far for camu-camu, with the exception of correlations with Brix value, which are generally positive (PINEDO-
PANDURO, 2012, 2013; NASCIMENTO et al., 2014). When the correlations among variables of cultivated plants were analyzed (results not shown), similar trends were found, except for ascorbic acid content, which showed a negative correlation with other variables. This suggests that larger fruits with higher vitamin $\mathrm{C}$ content are more frequent in uncultivated locations than in cultivated ones.

Table 2. Pearson's correlation coefficients between pairs of physicochemical characteristics of the fruits of 87 camucamu (Myrciaria dubia) plants in cultivated and uncultivated areas in Tarapacá, Colombia, 2018.

\begin{tabular}{llllllllll}
\hline & AA & FM & PM & PUY & MFD & FL & MSF & NSF & MO \\
\hline BX & -0.04 & -0.25 & -0.28 & -0.16 & -0.24 & -0.28 & -0.08 & -0.28 & 0.08 \\
AA & & 0.33 & 0.33 & 0.12 & 0.33 & 0.32 & 0.20 & 0.14 & 0.08 \\
FM & & & 0.97 & 0.14 & 0.98 & 0.96 & 0.67 & 0.45 & 0.32 \\
PM & & & & 0.38 & 0.95 & 0.92 & 0.47 & 0.42 & 0.22 \\
PUY & & & & & 0.13 & 0.13 & -0.62 & 0.00 & -0.26 \\
MFD & & & & & 0.95 & 0.67 & 0.45 & 0.31 \\
FL & & & & & & 0.66 & 0.36 & 0.36 \\
MSF & & & & & & & 0.35 & 0.46 \\
NSF & & & & & & & & 0.00 \\
\hline
\end{tabular}

BX: degrees Brix (\%); AA: ascorbic acid content (mg / $100 \mathrm{~g}$ of mesocarp + exocarp); FM: fruit mass (g); PM: pulp mass per fruit (g); PUY: pulp yield; MFD: mean fruit diameter (mm); FL: fruit length (mm); MSF: mass of seeds per fruit (g); NSF: number of seeds per fruit (un); MO: moisture (\%).

In the principal components analysis, variables with correlations greater than 0.9 (pulp mass, fruit length and fruit diameter) were excluded, as they are redundant with fruit mass (Table 2) and because they have less variability $(\mathrm{CV}<10 \%)$. The first three principal components (Figure 2) explained $73 \%$ of the total variance $(\mathrm{PC} 1=35 \%$; $\mathrm{PC} 2=$ $24 \%$; $\mathrm{PC} 3=14 \%$ ). The variables that are most associated with $\mathrm{PC} 1$ are mass of seed $(\mathrm{r}=0.90)$ and fruit mass $(\mathrm{r}=$ $0.84)$; those associated with $\mathrm{PC} 2$ are pulp yield $(\mathrm{r}=0.83)$ and Brix value $(\mathrm{r}=0.66)$; and with PC3 is ascorbic acid content $(\mathrm{r}=0.78)$. There is no evident grouping of plants in the principal component space (Figure 2).
As with previous studies (PINEDO-PANDURO, 2012; PAREDES-DÁVILA, 2013; NASCIMENTO et al., 2014; CHAGAS et al., 2015), the variables that discriminate best among camu-camu plants are Brix value, ascorbic acid content, fruit mass and pulp yield (Table 1, Table 2, Figure 2. Therefore, these variable were used to pre-select 19 elite plants from uncultivated locations. Among the selected plants, values for each variable ranged between 7.49 and 10.9 degrees Brix, between 238.5 and 347.8 for ascorbic acid content ( $\mathrm{mg} / 100 \mathrm{~g}$ dry sample), between 13.2 and 18.3 for fruit mass $(\mathrm{g})$ and between 0.81 and 0.87 for pulp yield. The 19 pre-selected plants can be considered promising materials for future breeding processes, although yields must be monitored for several years before proceeding. 


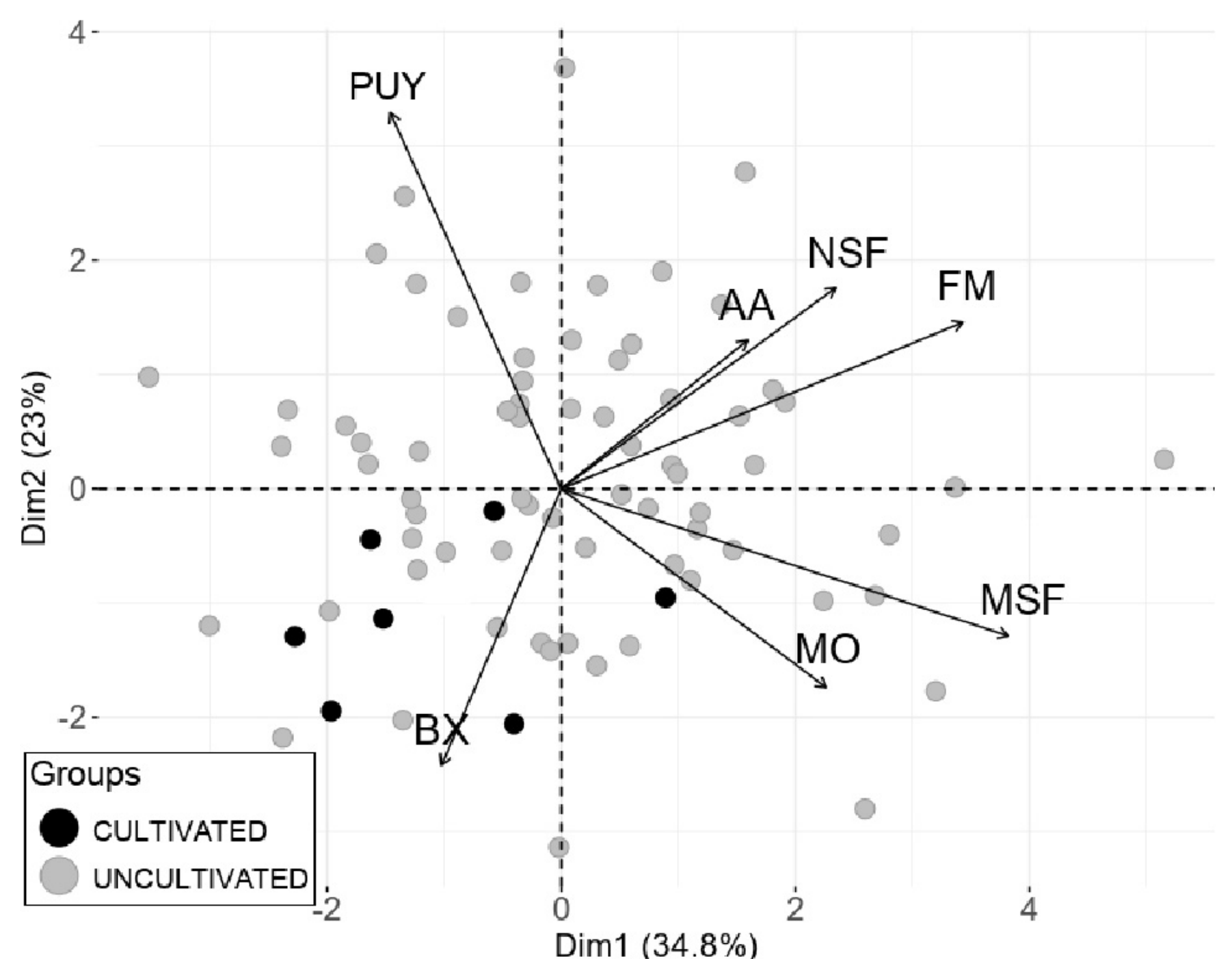

Figure 2. Principal component analysis for physicochemical characteristics of camu-camu (Myrciaria dubia) fruits in the Tarapacá region, Amazonas, Colombia.BX: degrees Brix; AA: ascorbic acid content; FM: fruit mass; PUY: pulp yield; MSF: mass of seeds per fruit; NSF: number of seeds per fruit; MO: Moisture number of seeds per fruit; MO: Moisture.

NSF:umber of seeds per fruit.

\section{Conclusion}

The camu-camu plants in Tarapacá, Colombia, have fruits with good characteristics for commercialization, improvement and conservation, and especially high values for fruit mass and degrees Brix. There is high variability within and between locations. Fruits of uncultivated plants present statistically higher values than those of cultivated plants for the variables ascorbic acid content, fruit mass and pulp mass, while cultivated plants had superior Brix values. The uncultivated locality Pechiboy had the plants with the best fruits.

\section{Acknowledgments}

We thank the inhabitants of Tarapacá and their traditional authorities for their hospitality, assistance and logistical support for this study. JCAN received a scholarship from the Graduate Students Agreement Program - PEC-PG of Capes / CNPq. Agrosavia kindly provided some of the camu-camu samples included in this study. MSR and CRC thank CNPq for research fellowships. 


\section{References}

ABANTO-RODRIGUEZ, C.; PINEDO-PANDURO, M.; ALVES-CHAGAS, E.; CARDOSO-CHAGAS, P.; TADASHI-SAKAZAKI, R.; MENEZES, P.; FARIASARAÚJO, W.; MURGA-ORRILLO, H. Relation between the mineral nutrients and the vitamin $\mathrm{C}$ content in camucamu plants (Myrciria dubia) cultivated on high soils and flood soils of Ucayali, Peru. Scientia Agropecuaria, Trujillo, v.7, n.3, p.297-304, 2016.

ALVES, R.E.; ALMEIDA, H.; FILGUEIRAS, C.; FARLEY, C.; MOURA, H.; ARAÚJO, C.C.; ALMEIDA, A.S. Camu-camu (Myrciaria dubia Mc Vaugh): A rich natural source of vitamin $C$. Proceedings of the Interamerican Society for Tropical Horticulture, San Jose, v.46, p.11-13, 2002.

AVILA-SOSA, R.; MONTERO-RODRÍGUEZ, A.F.; AGUILAR-ALONSO, P.; VERA-LÓPEZ, O.; LAZCANO-HERNÁNDEZ, M.; MORALES-MEDINA, J.C.; NAVARRO-CRUZ, A.R. Antioxidant properties of Amazonian fruits: a mini review of in vivo and in vitro studies. Oxidative Medicine and Cellular Longevity, San Jose, v.2019, p.1-11, 2019.

BENASSI, M.; ANTUNES, A.J. A comparison of metaphosphoric and oxalic acids as extractant solutions for the determination of vitamin $\mathrm{C}$ in selected vegetables. Arquivos de Biologia e Tecnologia, Curitiba, v.31, n.4, p.507-513, 1988.

BRASIL. Lei n.10.711 de 5 de agosto de 2003. Dispõe sobre o sistema nacional de sementes e mudas e dá outras providências. Diário Oficial da União, Brasilia, DF, 6 ago. 2003. Disponível em: http://www.planalto.gov.br/ ccivil_03/LEIS/2003/L10.711.htm. Acesso em: 17 dez. 2019.

CÁRDENAS, D.; LÓPEZ CAMACHO, R.; ACOSTA, L.E.; SINCHI. Experiencia piloto de zonificación forestal en el corregimiento de Tarapacá (Amazonas). Bogotá: Instituto Amazónico de Investigaciones Científicas - Sinchi, 2004.

CARVALHO, J.E.U.; MÜLLER, C.H. Biometria e rendimento percentual de polpa de frutas nativas da Amazônia. Belém: Embrapa Amazônia Oriental, 2005. p.1-3.
CHAGAS, E.A.; BARDALES-LOZANO, R.M.; CHAGAS, P.C.; BACELAR-LIMA, C.G.; GARCIA, M.I.R.; OLIVEIRA, J.V.; SOUZA, O.M.DE; MORAIS, B.S.; ARAÚJO, M.D.C. Intraspecific variability of camucamu fruit in native populations of northern Amazonia. Crop Breeding and Applied Biotechnology, Viçosa, MG, v.15, n.4, p.265-271, 2015.

CHERNICK, M. R.; LABUDDE, R. A. An introduction to bootstrap methods with applications to $R$. New Yersey: John Wiley \& Sons, 2011.

FREITAS, C.A.B.; SILVA, A.S.; ALVES, C.N.; NASCIMENTO, W.M.O.do.; LOPES, A.S.; LIMA, M.O.; MÜLLER, R.C.S. Characterization of the fruit pulp of camu-camu (Myrciaria dubia) of seven different genotypes and their rankings using statistical methods PCA and HCA. Journal of the Brazilian Chemical Society, Campinas, v.27, n.10, p.1.838-1.846, 2016.

FUJITA, A.; BORGES, K.; CORREIA, R.; FRANCO, B.D.; GENOVESE, M.I. Impact of spouted bed drying on bioactive compounds, antimicrobial and antioxidant activities of commercial frozen pulp of camucamu (Myrciaria dubia Mc. Vaugh). Food Research International, Burlington, v.54, n.1, p.495-500, 2013.

GRIGIO, M.L.; CHAGAS, E.A.; BERLINGIERI, D.M.F.; ANDRADE, S.A.de; MOTA, F.A.B.; CHAGAS, P.C. Determination of harvest time and quality of native camucamu fruits (Myrciaria dubia (Kunth) Mc Vaugh) during storage. Fruits, Lovaina, v.71, n.6, p.373-378, 2016.

HERNÁNDEZ, M.S.; BARDALES-INFANTE, X.; CRISTINA CARDONA, J.E.; RODRIGUEZ CAMACHO, C.; AHUANARY, A.; SOUZA, E. de. Uso y aprovechamiento del Camu camu en Tarapacá. In: HERNÁNDEZ, M.S.; BARRERA, J.A. (org.). Camu camu (Myrciaria dubia (Kunth) McVaugh). Bogotá: Instituto Amazónico de Investigaciones Científicas-Sinchi, 2010a. p.79-98.

HERNÁNDEZ, M.S.; BARRERA, J.A.; FERNÁNDEZTRUJILLO, J.P.; CARRILLO, M.P.; BARDALESINFANTE, X.; CRISTINA CARDONA, J.E.; POLANIA, A. Recolección y manejo poscosecha de Camu camu. In: HERNÁNDEZ, M.S.; BARRERA, J.A. (org.). Camu camu (Myrciaria dubia (Kunth) McVaugh). Bogotá: Instituto Amazónico de Investigaciones Científicas-Sinchi, 2010b. p.61-78. 
IMÁN-CORREA, S.; PINEDO-FREYRE, S.; MELCHOR ALDANA, M. Caracterización morfológica y evaluación de la colección nacional de germoplasma de camu camu Myrciaria dubia (H.B.K) Mc Vaugh, del INIA LoretoPerú. Scientia Agropecuaria, Trujillo, v.2, p.189-201, 2011.

INSTITUTO ADOLFO LUTZ. Métodos físico-químicos para análise de alimentos. 4. ed. São Paulo: Instituto Adolfo Lutz, 2008. 1020p.

IZQUIERDO GÓMEZ, D. D.; TONG GATTY, W. Exportaciones de productos del sector agro de la región Loreto, periodo 2011-2015. Iquitos: Universidad Nacional de la Amazonía Peruana, 2018. 88p.

JULIANO, F.F.; SILVA, P.P.M. da; CASEMIRO, R.C.; COSTA, M.H.; SPOTO, M.H.F. Polpa de camu-camu liofilizada e armazenada em diferentes embalagens. Revista Brasileira de Tecnologia Agroindustrial, Ponta Grossa, v.8, n.2, p.1.374-1.385, 2014.

MARTIN, M.P.PETERS, C.M.; ASHTON, M.S. Revisiting camu-camu (Myrciaria dubia): twenty-seven years of fruit collection and flooding at an Oxbow Lake in Peruvian Amazonia. Economic Botany, New York, v.68, n.2, p.169-176, 2014.

MORAIS, L. de C.; PINHEIRO, S.S. Nutrients and bioactive compounds of açai, bacuri, buriti, camu-camu, and cubiu. In: TODOROV, S.D.; PIERI, F. A. (org.). Tropical fruits: from cultivation to consumption and health benefits, fruits from the Amazon. New York: Nova Science Publishers, 2018. p.121-132.

NASCIMENTO, W.M.O. do; GURGEL, F. de L.; BHERING, L.L.; RIBEIRO, O.D.; SOARES, A.C.S.E. Avaliações preliminares de parâmetros genéticos de acessos de Myrciaria dubia por marcadores fenotípicos. Belém: Embrapa Amazônia Oriental, 2013.

NASCIMENTO, W.M.O. do; GURGEL, F. de L.; BHERING, L.L.; RIBEIRO, O.D. Pré-melhoramento do camucamuzeiro: estudo de parâmetros genéticos e dissimilaridade. Revista Ceres, Viçosa, MG, v.61, n.4, p.538-543, 2014.

NEVES, L.C.; SILVA, V.X. da; PONTIS, J.A.; FLACH, A.; ROBERTO, S.R. Bioactive compounds and antioxidant activity in pre-harvest camu-camu [Myrciaria dubia (H.B.K.) Mc Vaugh] fruits. Scientia Horticulturae, New York, v.186, p.223-229, 2015.

OLIVEIRA, M. do S.P. de; MARQUES, D.N.; MATTIETTO, R. de A.; NASCIMENTO, W.M.O. Desempenho agronômico de clones de camucamuzeiro nas condições de terra firme, em Belém, PA. Belém: Embrapa Amazônia Oriental, 2018. 24p.

PAREDES-DÁVILA, E. Comparativo de 37 clones de camu camu arbustivo Myrciaria dubia (H.B.K) Mc Vaugh, en Loreto en el sexto año de su instalación. 2013. Tese (Engenheiro Agronomo) - Universidad Nacional de la Amazonia Peruana, Iquitos, 2013. 198p.

PINEDO-PANDURO, M. Análisis de correlación y heredabilidad en el mejoramiento genético del camucamu. Scientia Agropecuaria, Trujillo, v.1, p.23-28, 2012.

PINEDO-PANDURO, M. Correlation and heritability analysis in breeding of camu-camu [Myrciaria dubia (Kunth) McVaugh]. African Journal of Plant Science, Jharkhand, v.7, n.2, p.61-66, 2013.

PINEDO-PANDURO, M. Seleção de genótipos superiores em coleções ex situ de camu-camu [Myrciaria dubia (Kunth) McVaugh] da Amazônia peruana. 2017. Tese (Doutorado) - Universidade Federal de Roraima, Boa Vista, 2017. 141p.

PINEDO-PANDURO, M.; DELGADO VASQUEZ, C.; FARROÑAY, R.; IMÁN-CORREA, S.; VILLACRÉS VALLEJO, J.; FACHIN MALAVERRI, L.; OLIVA CRUZ, C.; ABANTO-RODRÍGUEZ, C.; BARDALESLOZANO, R. M.; VEGA VIZCARRA, R. Camucamu (Myrciaria dubia, Myrtaceae): aportes para su aprovechamiento sostenible en la Amazonia peruana. Lima: Instituto de Investigaciones de la Amazonia Peruana, 2010.

PINEDO-PANDURO, M.; LINARES, C.; MENDOZA, H.; ANGUIZ, R. Plan de mejoramiento genético del camu camu. Iquitos: Instituto de Investigaciones de la Amazonía Peruana - IIAP, 2004. 54p.

PNUMA; OTCA. Perspectivas do meio ambiente na Amazônia Geo Amazônia. Ciudad de Panamá: Centro de Pesquisa Universidad del Pacifico, 2008. 323p.

PROMPERU. Informe anual 2017. Desenvolvimiento del comercio exterior agroexportador. Lima: Departamento de Agronegocios de la Sub Dirección de Promoción Internacional de la Oferta Exportable, 2018. 150p.

R DEVELOPMENT CORE TEAM. R: a language and environment for statistical computing. Viena: Foundation for Statistical Computing. 2018. Disponível em: www.rproject.org. Acesso em: 8 ago. 2019. 
RIBEIRO, S.I.; MOTA, M.D.C.; CORRÊA, M.L.P.; MONTEIRO, L.L.Avaliação de acessos de camucamuzeiro Myrciaria dubia (H. B. K.) Mc. Vaugh oriundos do Alto Solimões. In: FRAZÃO, D.A.C.; HOMMA A.K.O.; VIÉGAS I.D.J.M. (org.). Contribuição ao desenvolvimento da fruticultura na Amazônia. Belém: Embrapa Amazônia Oriental, 2006. p.245-250.

RINCÓN, E.; MURCÍA, U.G.; HUERTAS, C.; RODRÍGUEZ, J.; CASTELLANOS, H. Fichas técnicas de los patrones de las coberturas de la tierra de la Amazonia colombiana. Bogotá: Instituto Sinchi, 2009.

SILVA, M.A.da;ARÉVALO PINEDO, R.; KIECKBUSCH, T.G. Ascorbic acid thermal degradation during hot air drying of camu-camu (Myrciaria dubia [H.B.K.] McVaugh) Slices at different air temperatures. Drying Technology, London, v.23, n.9-11, p.2277-2287, 2005.

ŠMÍD, J.; KALOUSOVÁ, M.; MANDÁK, B.; HOUŠKA, J.; CHLÁDOVÁ, A.; PINEDO-PANDURO, M.; LOJKA, B. Morphological and genetic diversity of camu-camu [Myrciaria dubia (Kunth) McVaugh] in the Peruvian Amazon. PloS One, San Francisco, v.12, n.6, p.1-15, 2017.
SOUZA, A. L. R. de. Estabilização de moléculas bioativas presentes em suco de camu-camu (Myrciaria dubia (H.B.K) Mc Vaugh) pela integração dos processos de osmose inversa, evaporação osmótica e atomização. 2012. Dissertação (Mestrado) - Universidade Federal Rural do Rio de Janeiro, Seropédica, 2012. 59p.

TILLMANS, J. Über die Bestimmung der elektrischen Reduktions-Oxidations-Potentiale und ihre Anwendung in der Lebensmittelchemie. Zeitschrift für Lebensmitteluntersuchung und-Forschung, Berlin, v.54, n.1, p.33-43, 1927.

ZANATTA, C.F.; CUEVAS, E.; BOBBIO, F.O.; WINTERHALTER, P.; MERCADANTE, A.Z. Determination of anthocyanins from camu-camu (Myrciaria dubia) by HPLC-PDA, HPLC-PS, and NMR. Journal of Agricultural and Food Chemistry, Washington, v.53, n.24, p. 9531-9535, 2005.GENE 